\title{
CENTO E OITENTA GRAUS NA CURVA EVOLUTA DAS EMOÇÕES: AS PERSONAGENS FEMININAS DE FERNANDA BOTELHO
}

Maria José Somerlate Barbosa University of Iowa

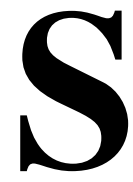

aídas de circunstâncias do dia-a-dia, as personagens de Fernanda Botelho movimentam-se numa esfera quase cinematográfica. Durante a locomoção das personagens, as narrativas examinam os efeitos da reformulação da sociedade portuguesa através da análise do comportamento feminino, da interação dessas mulheres com o seu meio ambiente e da sua reação contra imposições sócio-culturais. As personagens posicionam-se no princípio das narrativas como pessoas manipuladas, passivas e sem vontade própria. São apresentadas inicialmente quase como desenhos animados, pinturas, caricaturas e fantoches. Ao passo que a trama se desenvolve, elas vão crescendo na "curva evolutiva das emoções sofridas" até perfazerem uma amplitude que Botelho classifica como sendo "de cento e oitenta graus" (Calendário 156).

A gata e a fábula (Prêmio Camilo Castelo Branco) constitui um dos textos mais importantes de Botelho pois é nele que a técnica narrativa, bem como a crítica social mais acirrada, tornam-se eixos embrionários que, de muitas maneiras, passam a definir o romance botelhiano. Quanto à estrutura narrativa, Xerazade e os outros é, sem dúvida, o romance de Botelho no qual a crítica tem concentrado mais atenção. Fernando Mendonça acredita que Xerazade "não tem história - tem apenas personagens", porque sendo um romance moderno não tem "núcleo narrativo" a partir de onde evole a "intriga que leva à solução final" ("Fernanda Botelho", 159). Considerando 
essa quebra dos moldes tradicionais de narrar como uma emancipação ou "libertação do transcurso geral da aventura", Mendonça elege Xerazade e os outros como o protótipo de tal mudança no romance botelhiano. Conclui que esse texto é um bom exemplo de quão pouco importante a "urdidura da narrativa" se torna quando o desenvolvimento dos personagens estabelece bem a trama narrativa. No entanto, tal particularidade se encontra praticamente em todos os romances botelhianos, pois são as personagens - e nem tanto o enredo - que evidenciam a mestria do seu processo criativo.

As personagens de Botelho exibem uma fascinação pela escrita e/ou pintura. É raro um texto seu em que não haja uma referência a textos literários, a pintores e outras obras de arte. Muitos dos seus romances apresentam personagens que se dedicam à pintura e/ou à literatura (como passatempo ou como profissão) e/ ou que escrevem diários, narrativas epistolares, biografias e autobiografias. Dentre a longa lista de pintores citados na obra de Botelho, Brueghel ocupa um lugar de destaque, provavelmente pelas semelhanças que a própria Botelho vê entre a sua escrita e a pintura de Brueghel. Ele se destacou pela arte de retratar movimentos, pintando as pessoas em contato físico umas com as outras, engajadas nas suas atividades cotidianas. Captou também as tensões sociais, políticas e religiosas da Holanda da sua época. ${ }^{1}$ Em A gata e a fábula Botelho faz referências a Brueghel e apresenta "uma espécie de teoria bruegheliana sobre a fealdade das pessoas e dos seus atos" (246) que é mencionada e examinada em romances subsequentes, especialmente em Lourenço é nome de jogral e Esta noite sonhei com Brueghel (Prêmio da Crítica). Por exemplo, Luíza desejaria incorporar no seu texto e na sua vida o mesmo "exagero" de viver, uma certa "glutonice" emocional, a "truculência," os "apelos

${ }^{1}$ Veja Teresa Moura Guedes, "Bruegel e Fernanda Botelho," Colóquio/Letras 102 (Março-Abril 1988): 102-06; Max J. Frieddænder, Early Netherlandish Painting: From Van Eyck to Bruegel (London: Phaidon Press, 1956); Teréz, Gersi Brueghel and His Age (New York: Taplinger Publishing Company, 1970). 
da rude terra" e "o cio da tosca gente" que vê na pintura de Brueghel (Esta noite, 172).

Toda a obra de Botelho exibe também uma fascinação com a geometria que representa diversos tipos de relações. Ângulos, vértices, curvas e triângulos são usados como metáforas de relações afetivas e sexuais, tornando-se índices da evolução pessoal das personagens e indicando também os jogos e relações de poder dentro do texto. As mulheres na obra de Botelho procuram e encontram uma certa "obliquidade" para evitar o confronto direto com o mundo. A elação atribuída a essa "obliqüidade" das personagens femininas contrasta com o desprezo narrativo pela "perpendicularidade" evidenciada nas personagens masculinas.

Uma das técnicas narrativas mais eficientes que Botelho utiliza na elaboração das suas personagens femininas é a constante dissenção entre o parar nas tradições enraizadas e o reformular tais padrões. Esse conflito produz um movimento, uma fricção de desencontrados desejos e uma tensão criada pelas paixões das personagens. Por isso, as protagonistas de Botelho acabam sempre partindo, mudando, escapando do seu meio ambiente. A geografia multifacetada (Bruxelas, Coimbra, Lisboa, Minho, Viseu, Paris) exemplifica a constante movimentação física das personagens. A preocupação dessas mulheres com a simbologia geométrica indica a sua tentativa de redimensionar o seu espaço físico, psicológico e social.

A sedimentação de princípios dicotômicos entre aceitação passiva e rompimento com tradições vai-se delineando como zonas de conflito na prosa botelhiana. Usada para desmistificar uma sociedade portuguesa descrita como patriarcal, convencional e classista, a intriga romanesca de Botelho acaba estabelecendo um paradigma de relações que, à primeira vista, poderia ser considerado dialético, como o querem alguns críticos. Fernando Mendonça, por exemplo, acredita que é "nessa dialética de relação que se institui o conflito permanente do meio circundante com as personagens" ("As relações humanas", 160). No entanto, essa dicotomia (aquietarse ou transformar-se) nunca chega a uma síntese, pois a tese e a 
antítese bifurcam-se em múltiplas relações pessoais nos romances de Botelho. Ao incorporar o questionamento aos padrões sociais, as personagens passam a reivindicar direitos e exigir mudanças num processo em que o texto vai continuamente se bifurcando. Consequentemente, mais do que dialética, a relação das personagens com as outras e com o seu meio ambiente é dialógica, ${ }^{2}$ processo exemplificado através da estrutura narrativa. Os capítulos e/ou as partes - como madeixas de uma trança - vão se entrecortando e se reunindo, estabelecendo ao mesmo tempo um sistema de união e separação de uma parte da outra.

Botelho faz inúmeras referências à desolação artística, social e política da época salazarista, discute a dinâmica das relações entre homens e mulheres e contextualiza muitos eventos e personagens na tradição literária portuguesa. Tais posicionamentos se apresentam desde os seus primeiros romances e são enfatizados a partir de Terra sem música. Neste romance, Antônia e Cristina escutam uma canção intitulada "Land Without Music" e estabelecem uma relação simbólica entre a "terra sem música" e Portugal. Referem-se às questões sociais, à austeridade, à balança comercial deficitária, à mão armada, aos impostos altos e ao descontentamento do povo. Em Lourenço é nome de jogral, as imagens de isolamento, alienação e tristeza são apresentadas como reflexos dos efeitos da ditadura em Portugal. Até mesmo Dramaticamente vestida de negro (Prêmio Pen Clube Português), o seu último romance, faz uma ligeira menção ao regime salazarista e ao estabelecimento da democracia em Portugal, ao apontar as razões do exílio que Cleo se impôs e como a "Revolução dos Cravos" levou-a a retornar a Portugal.

Os nove romances de Botelho foram escritos no decorrer de quase quarenta anos, espaço temporal em que a sociedade portuguesa passou por uma estagnação político-social e sofreu os efeitos morais e culturais de estar sob a mira de um regime

${ }^{2}$ Para o conceito de "dialogismo," veja Mikhail Bakhtin, The Dialogic Imagination: Four Essays (Austin: University of Texas Press 1981). 
governamental retrógado e autoritário. Os textos de Botelho freqüentemente ironizam o provincialismo e o autoritarismo de certas medidas governamentais que conseguiram reforçar os ditames de uma sociedade profundamente enraizada numa mitologia nociva à mulher. As personagens comentam ou discutem os efeitos de leis passadas e medidas tomadas no regime salazarista cujo objetivo era relegar as mulheres exclusivamente ao espaço doméstico, exercendo um acirrado controle sobre a sua locomoção no espaço fora de casa e na escala social. Era parte da política misoginista do regime de Salazar punir severamente qualquer "audácia" por parte das mulheres que porventura contrariassem as leis estabelecidas em nome da fé, da moral e dos bons costumes. ${ }^{3}$ No entanto, ainda que haja muita preocupação com questões políticas e sociais, nos livros de Botelho, a crítica não se torna uma forma panfletária ou um documento de cunho estritamente histórico. Aliada à trama narrativa, a crítica social e política nos romances botelhianos projeta-se a nível da consciência das personagens femininas.

Contextualizando as suas personagens no momento históricocultural português e na tradição literária mundial, Botelho utiliza largamente a ironia e a paródia para desmistificar o sistema patriarcal cheio de meias-verdades, hipocrisia e descaso pela mulher. Em Terra sem música, Antônia menciona que na "literatura as mulheres são realmente um tema que dá pano para as mangas" (209). E pormenoriza a explicação num tom parodístico:

Refiro-me, minha cara, à mulher encarada no plano das generalidades, sem qualquer individualização, como espécie devidamente caracterizada, substantivo comum amplamente adjectivado. Dizemos: os fitozoários são animais de simetria radiada; os números decimais ilimitados e não periódicos chamam-se irracionais; a mulher é um animal absurdo, pleonástico, metafórico e paradoxal, os instrumentos de percussão ressoam quando eles lhe batem. (210)

${ }^{3} \mathrm{O}$ exemplo mais divulgado dessa misoginia salazarista foi a prisão das escritoras Maria Isabel Barreno, Maria Teresa Horta e Maria Velho da Costa cuja escrita foi considerada erótica e desacatante à moral e aos bons costumes. 
Em Lourenço é nome de jogral, Botelho também criticamente avalia a posição da mulher na sociedade portuguesa, utilizando-se de referências literárias consagradas (Bernadim Ribeiro, Homero/Joyce, Fernando Pessoa, Almeida Garrett) e papéis sócio-sexuais (meretrício, adultério, castidade, virgindade) comumente associados à sexualidade feminina, como se pode ver no seguinte trecho, extraído do longo poema "Matilde":

menina e moça ai menina e moça
filha de Ulisses por ele enjeitada
de Dom Sebastião sepulcral noiva
mística esposa do oceano adúltero
mãe virgem devassada em sete seios
ei-la perversa musa despojando-se
do cinto de castidade para a noite
toda em vidrilhos toda em lantejoilas
pirilampeando Alfama abaixo
ai menina e moça ai menina e moça
tudo vale a pena tudo vale a pena
menos isto menos isto menos isto
sereia que te espreguiças mutilada
Nós vamos de mão dadas ver o Tejo. (128)

Botelho freqüentemente descontrói mitos formulados em torno da imagem e da representação da mulher. Em Calendário privado, Novaes, um amigo campesino da família de Aninha, expõe a mitificação em torno da criação do mundo, explicando detalhadamente como e porquê cabe à mulher a culpa dos problemas que o homem enfrenta. A explicação aparentemente simplória mas profundamente misoginista do morgado, que poderia ser cômica se não fosse tão ofensiva a Aninha, leva-a, a caminho de Aveiro, a ponderar sobre o assunto, considerando que o Morgado transferira a sua ira para ela, personificando nela "o símbolo da Inimiga e da Perdição" (225). A crítica a uma mitologia do comportamento feminino mostra-se também explícita em O ângulo raso e em $A$ gata e a fábula em que a descrição repetida de "gata" e o próprio título da narrativa apontam para a paródia que Botelho faz desses estereótipos. As imagens felinas e a representação da mulher pelo 
olhar masculino se misturam acentuadamente em O ângulo raso, principalmente na passagem em que Tom está na casa de Lúcia observando-a dormir. Fitando-a intensamente e classificando-a de gata, serpente e leoa, ele a elege como uma "perfeita" representante do sexo feminino, cheia de "movimentos elásticos e felinos" (134). ${ }^{4}$

O olhar ganha uma dimensão especial em toda a obra de Botelho. Em Xerazade e os outros, ela apresenta a noção do olhar prescrutador masculino estereotipando a imagem da mulher. Antônia (personagem de Terra sem música) contenta-se sempre em olhar, procurando nas pessoas e nos vultos uma explicação plausível para o seu "estar no mundo". Também em Esta noite sonhei com Brueghel, através do olhar, Luiza recria as personagens do pintor, "dotando-as de movimento, de vontade de ser" (Guedes 103). Esta maneira de "olhar" o mundo como objeto a ser analisado e analisável inscreve o momento de auto-avaliação, do auto-reconhecimento, da relativização social perpetuada pela relação especular entre o "Eu" (sujeito) e o "Outro" (objeto). Essa identificação/diferenciação das personagens leva-as a articularem um conceito sobre si mesmas que se torna a representação simbólica do "Outro" como passivo e observado.

Os romances botelhianos direcionam a atenção para assuntos geralmente associados com a sexualidade e sensualidade femininas: casamento, adultério, virgindade e prostituição. Seus textos discutem papéis masculinos e femininos, formação de mitos e estereótipos, busca de identidade, reivindicação de direitos igualitários e questionamento de instituições como o casamento e a maternidade. Também remetem o leitor a discussões críticas já abalizadas como a representação da mulher como objeto de prazer e desejo masculino.

Muitas das considerações sobre a mulher que Fernanda Botelho desenvolve ao longo da sua prolífica obra, ela já delineara

${ }^{4}$ Os desenhos/quadros de Júlio Pomar que aparecem nas capas dos romances de Botelho (Editora Contexto) refletem o movimento, os medos e ansiedades dos tigres/pessoas enjaulados que Botelho descreve nos seus romances. 
em A gata e a fábula. Neste romance, o narrador explica que a "fábula" é em grande parte uma mitologia nociva sobre a mulher. Questionando profundamente os fundamentos culturais e sociais da sociedade portuguesa, o narrador de A gata e a fábula condena o sistema patriarcal que construiu-se como "pedra," tornando-se uma "força" e "uma evidência do passado" agindo sobre o presente (83). Neste mesmo texto - cuja história se passa em torno da Segunda Guerra Mundial - o narrador também analisa a posição da mulher em Portugal, comparando o patriarcalismo vigente à "Arqueologia - Arte feita silêncio" (85).

Paula Fernanda, protagonista de A gata e a fábula, cresce corajosa e destemida, desobrigada de certas virtudes "femininas", desafiando e desobedecendo pessoas que tentavam subjugá-la. Após a morte da mãe, ela se transforma numa jovem que preenche todos os requisitos de uma "ótima dona-de-casa" e tutora amantíssima. Ela se revela econômica, criativa, dinâmica, trabalhadora, capaz de equilibrar bem os parcos recursos financeiros da família durante a Segunda Guerra Mundial, hábil no trato e cuidados com o pai viúvo e responsável pela garota Rosinha (desta maneira se redimindo também através do papel de mãe). A inversão da hierarquia doméstica e do poder de decisão - era Paula, e não o pai ou o irmão, que geria os negócios, a casa e as finanças da família indicam que a sua inclusão no mundo da casa e dos afazeres domésticos tornava-a "prendada" aos olhos do seu mundo.

À primeira vista, portanto, parece que a nova imagem de Paula serve para resgastar-lhe uma representação "feminina" que não se delineara na sua infância e adolescência. A nova imagem de Paula (extremada dona de casa e filha abnegada) contrasta com a antiga representação dela (menina rebelde alheia às vicissitudes "femininas" cujo espaço social era primordialmente fora de casa). E é exatamente quando incorpora o papel de "perfeita" dona-decasa, participando inteiramente da "aprendizagem" feminina, que ela recebe atenção especial de Duarte Henrique, pretendente que a rejeitara na adolescência, pois a considerara promíscua e liberal 
demais. Uma vez que ela se conformou às medidas sócio-culturais "femininas," Duarte Henrique pede-lhe a mão em casamento (união que ela recusa). Ainda que tenha sido através do seu casamento com Afonso que Paula tenha conseguido escapar aos ditames da família, ela inaugurou uma nova etapa no meio social a que pertence, pois o seu elo matrimonial se fez por amor e não por conveniência ou imposição da família, como acontecera à sua mãe.

Grande número das personagens femininas de Botelho submetem-se a relações matrimoniais insatisfatórias, permanecendo no círculo vicioso das suas esferas sociais e deixando-se "domesticar" e apropriar como são os casos de Maria Luísa (Xerazade e os outros) e Luiza (Festa em casa de flores). Xerazade utiliza o casamento como forma de ascendência social. Essa última faceta, Botelho já apontara em A gata e a fábula, mostrando como o desenvolvimento da sexualidade feminina tem sido ligado ao casamento como uma aliança social, econômica e política. Através da ironia e da paródia, Botelho discute em A gata e a fábula muitos aspectos sociais/sexuais (como o casamento e o meretrício) costumeiramente relacionados às mulheres. Neste texto, ela desmistifica a idéia da prostituição vista pela sociedade patriarcal como "um mal necessário" e ironiza a "poética" da união extra-conjugal, a posição dos filhos bastardos e a "farsa dos amores malditos," lugares comuns na literatura portuguesa. ${ }^{5}$

Botelho parodia o casamento visto como um investimento social e econômico. Demonstra que, num país profundamente católico como o é Portugal, o casamento passa a ser uma das intituições mais hipócritas daquela sociedade sendo usado também como veículo de manipulação do Estado. ${ }^{6}$ Camuflado pelo véu da ideologia pequeno-burguesa, que considera a união matrimonial um

${ }^{5}$ A vida e a morte de Inês de Castro constitui o exemplo mais clássico da "poética" do amor extra-conjugal e dos filhos bastardos na história/literatura portugesa.

${ }^{6}$ Basta lembrar-se dos famosos "Casamentos de Santo Antônio" implementados no regime salazarista. 
elo indissolúvel e santificado, casos como o casamento de Manuel, amante de Aninha (Calendário) passam a indicar o jogo de intrigas e de duplos valores morais existentes na instituição matrimonial. Os casamentos por conveniência ou como forma de ascensão na escala sócio-econômica geram, via de regra, personagens que procuram no adultério a sua válvula de escape. Mesmo quando o casamento não traz como prêmio/dote essa subida na escala social, continua a ser uma prisão, pois as obrigações com a família se tornam um fardo (como é o caso de Maria da Luz em A gata e a fábula).

O adultério perfaz toda a obra de Botelho, mas é em Lourenço é nome de jogral e Esta noite sonhei com Brueghel que as tramas se tecem especificamente em torno de triângulos amorosos. Evitando transformar as personagens femininas em meras vítimas de situações sócio-culturais, Botelho analisa a questão do adultério minuciosamente. Apresenta a infidelidade conjugal feminina como veículo de expressão da sua insatisfação reprimida, discute a inabilidade das personagens de se rebelarem contra um sistema em que são consideradas objetos disponíveis ou mercadoria de troca (como é o caso de Maria Luísa em Xerazade) e examina a conivência da mulher com tal sistema. Mais que a participação individual em tais casos, Botelho critica o aparato social que favorece, fermenta e institucionaliza as situações e convenções determinantes da infidelidade matrimonial.

Na sua discussão sobre a artificialidade dos papéis masculinos e femininos, Botelho mostra o que Sandra Bartky considera categorias de "práticas disciplinares". Essas práticas, explica Bartky, produzem um corpo "feminino" e definem o que é a subjetividade e identidade femininas. A primeira das divisões de Bartky se refere à configuração física das personagens; a segunda mostra um repertório específico de gestos, posturas e movimentos; e a terceira categoria é aquela que exibe o corpo como uma superfície ornamental. ${ }^{7}$ É nesta última categoria que Botelho coloca a Maria Luísa

${ }^{7}$ Veja Sandra Lee Bartky, "Foucault, Femininity, and Modernization of Patriarchal Power," Feminism and Foucault: Reflections on Resistance (Boston: Northeast University Press, 1988). 
(Xerazade) para parodiar um sistema que, ao criá-la, simultaneamente a rejeita. Botelho sistematicamente analisa a posição de Xerazade que se mede e se deixa medir superficialmente, codificando-se também pelo medo de ficar velha.

As relações interpessoais, a "nível de pele", primeiro se delineiam em A Gata e a fábula com as constantes referências de Duarte Henrique à pele de Yvette, sua namorada francesa. Também mencionada em Terra sem música onde, durante um dos encontros de Antônia com o misterioso "senhor H", ele lhe afirma repetidas vezes que gosta muito da sua pele. Este relacionar-se "à flor da pele" torna-se tópico principal em Xerazade e os outros. Carlos Aloisius freqüentemente alude à pele de Maria Luísa, índice e símbolo da superficialidade das relações entre eles. Ela é também depurada pelo olhar das outras personagens que interpretam mal o discurso do seu tempo e espaço, os seus gestos e o seu corpo.

O espaço sócio-cultural que cada personagem ocupa nos romances de Botelho tem papel preponderante no seu desenvolvimento como pessoa. Nos casos em que as personagens femininas não ocupam uma área que as aprisiona fisicamente, elas estão encarceradas num determinado espaço social, econômico e sexual (como é o caso de Maria Luísa). O espaço funciona como a moldura de um espelho ou um quadro em que Botelho pinta e, às vezes, caricaturiza as personagens. O arcabouço espacial em que as pessoas se encaixam delimitam as suas zonas de movimento e passam a representar a sua condição social, refletindo o seu aprisionamento físico e psicológico. A mãe de Paula Fernanda ( $A$ gata e a fábula) define bem o espaço de fora da casa em confronto com o espaço de dentro da casa ao explicar que no seu tempo de menina "o barulho seria todo fora de casa" pois "dentro de casa era necessário manter a compostura. A compostura e o respeito pela doença e pela agonia, coisas habituais e comuns, dentro de casa" (21).

Ainda que a casa venha a ser, em muitos casos, a moldura em que Botelho encaixa suas personagens femininas, os seus textos abarcam espaços muito maiores. A relação protagonista e espaço se 
estabelece também nos seus afetos e desafetos com o seu meio ambiente e nas atmosferas sociais. Vê-se, portanto, que a casa (nomeadamente um espaço feminino) não aparece nos romances de Botelho como signo de abrigo ou ninho que protege e ampara. A casa é, acima de tudo, um espaço social em que se inserem desamparos e desamores, menos aparente em outros contextos. Quando as mulheres da obra de Botelho pertencem a classes mais privilegiadas, elas freqüentemente se tornam prisioneiras da sua posição social, como é o caso de Flores (em Festa em casa de Flores e Esta noite sonhei com Brueghel). Quando pertencentes às classes menos privilegiadas, as mulheres também se fazem prisioneiras de casamentos arranjados para satisfazer o interesse da família ou para ascensão social e econômica (como a Maria Luísa de Xerazade e Dona Carminho de Esta Noite sonhei com Brueghel) ou pela integração num nível de prestígio intelectual (Luiza em Esta noite).

Através da paródia aos contos de fada, Botelho analisa as mitologias repressivas que forjam imagens de subordinação da mulher através da domesticação do desejo e da celebração do "eterno feminino". Os textos de Botelho criticam o processo celebratório de se iniciar uma moça no ritual da espera em que seu máximo potencial como pessoa se realizará quando, despertada para a vida adulta, for guiada pelas mãos de um valente cavalheiro. É num clima de "belas adormecidas" e "gatas borralheiras" que Botelho encaixa muitas das personagens femininas. Através da representação das protagonistas, ela mostra como os contos de fada iniciam as meninas num processo de internalizar aspirações em que o seu máximo potencial se traduzirá em servir e amar o seu príncipe

${ }^{8}$ Esta tradução do inglês para o português é minha. Veja K. K. Ruthven, "Dismantling Androcentric Assumptions," Feminist Literary Studies: An Introduction (Cambridge: Cambridge University Press, 1984) 80-81. Para outras referências sobre contos de fada e feminismo veja Rosalind Coward, Female Desire: Women's Sexuality Today (New York: Grove Weindenfeld, 1985); e Marie Louise von Fraz, The Feminine in Fairy Tales (Ann Arbor, Michigan: Spring Publications, 1972). 
encantado. Botelho exemplifica nos seus romances o que K. K. Ruthven explica como uma prática sócio-cultural cujo objetivo é endocrinar as meninas. Considera que "[o]s contos de fada são formas culturais que ajudam a consolidar a crença de que a melhor coisa que pode acontecer a uma moça (a construção passiva do significante) é apaixonar-se, casar-se e ter muitos filhos". ${ }^{8}$

Como Maria Luíza (Xerazade e os outros), muitas das mulheres dos romances botelhianos aprendem a esperar que um homem bondoso e rico venha resgatá-las do seu restrito espaço sóciocultural e econômico. Botelho indica que tais limitações pessoais ensinam a passividade absoluta às mulheres, celebram a espera do destino traçado por mãos estranhas e representam a mulher como ser incapaz de escolher, agir ou mudar o curso de eventos na sua vida. Duarte Henrique, personagem de A gata e a fábula, ao pensar em sua ex-namorada Henriqueta, lembra-se que, ao conhecê-la, tinha associado a sua imagem a leituras infantis, contos de fada e fábulas:

Perrault e La Fontaine em simbiose, tudo muito ajustado a uma jovem princesa a quem as boas almas haviam prevenido contra os lobos, os leões, os piratas, as velhas encarquilhadas e perversas, o Rei Mar, a Maçã Proibida... Alice no País dos... Em suma: a dona do chapéu de chuva parecia arisca e entretelada pelo conhecimento de todas as ciladas. (159)

Semi-adormecida, à espera do seu príncipe encantado, Aninha (Calendário privado) recusa tanto a oferta de casamento de João quanto a de Edmundo, pois fica à espera, por mais de vinte anos, de um Manuel profetizado pela vidente. Aninha vai alinhavando o passado (constituído pela figura dos pais, parentes, amigos, namorados e a vidente Senhora Maria/Bruxa do Lameiro), o presente (feito de esperas) e o futuro (representado por Manuel, o varão principesco que a vidente previra na vida dela). Aninha carrega a pesada sombra do passado na voz da Bruxa que lhe repetiu um nome de homem, marcando-lhe a vida. No desenvolver da trama, as ironias do texto mostram de forma elaborada que, ao descartar todas as oportunidades amorosas que lhe aparecem, como a Penélope do 
texto clássico, Aninha vive a fantasia da espera. No entanto, nem príncipe encantado rico e charmoso, nem varão desimpedido e leal, aparece-lhe um Manuel casado, mesquinho e egoísta.

Quando finalmente compreende os labirintos da sua inércia e os desapontamentos advindos do processo, Aninha rejeita tal posicionamento. A voz narrativa explica essa tomada de consciência: "Não lamentava as ruínas. Lamentava somente a pequena Aninha que ouvira a Bruxa do Rego Lameiro uivar um nome; fixara esse nome e atribuíra-lhe uma importância determinante" (238). É no "calendário privado da sua memória" (263) que Aninha percebe que o passado - símbolo de família, tradição e destino traçado interfere com a sua realização como pessoa no presente. E, para desfazer os nós daquele fio de vida, ela decide voltar ao "princípio" na tentativa de dissolver o destino pré-fixado pela Bruxa. No final, ao ter a coragem de romper com ele e ir à procura de mudar o "princípio," ela aprende a procurar em si mesma a sua redenção e o seu caminho pessoal. É essa reavaliação de sua postura diante do mundo e de si mesma que se torna o ponto (des)articulador da narrativa.

Botelho inverte o processo de mitificaçao feminina em $O$ ângulo raso. Jeca representa o oposto da Bela Adormecida, pois transpõe seus medos, dúvidas e ansiedades indo bater à porta de um Tom, doentio e adormecido para acordá-lo do torpor no qual a morte de Lúcia o colocara. Jeca também se torna instrumental em fazê-lo aperceber-se dos seus preconceitos e reajustar-se a uma vida em que ele não a veja como gata, leoa, serpente, flor, Mona Lisa ou Medusa, mas como uma Jeca de carne e ossos, de sonhos, desejos, aspirações e vontade própria. Por isso, Tom refere-se a Jeca como uma princesa situada numa sociedade moderna: “- Eis que os papéis se invertem: agora é a princesa que vem despertar o príncipe adormecido" (249). Tal passagem do romance remete o leitor à inversão de valores/papéis que mitificaram as coordenadas do movimento feminino mundo afora. Botelho critica as correntes patriarcais que, contrárias à emancipação feminina, se serviram desse 
argumento para questionar e ridicularizar a validade das mudanças reivindicadas pelas mulheres.

Ao encarar o seu torpor e mal-estar físico como um sintoma da sua própria condição como pessoa, num casamento que se realizou por interesse, Maria Luíza (Xerazade e os outros) reage, decidindo se separar do marido. Corta as amarras que a prendem a uma vida que se reflete tanto na superficialidade com que ela se relaciona com as pessoas quanto nos abusos psicológicos que ela permite que o marido lhe inflija. Na maior parte do romance, Maria Luíza se encaixa na moldura de menina pobre que vende sua juven-tude e corpo a um casamento de conveniência. Por isso, o significado que a quebra dos seus vínculos com as relações anteriores passa a ter no final do romance. Como outras personagens do romance botelhiano, Maria Luíza reconhece que a sua porta de saída não vai ser nem fácil nem cômoda pois requer dela a coragem desafiante de partir para um novo e desconhecido mundo. Esse novo caminho exigirá dela uma visão analítica muito mais ampla, profunda e verdadeira de si mesma e das suas relações com outras pessoas.

Botelho constantemente leva as suas personagens a repensarem a importância de assumir responsabilidade pelos seus atos. Cláudia, personagem de Oângulo raso é prisioneira de uma situação de conveniência e dos ditames de "fémme fatale" (ela é casada, o marido é uma figura misteriosa, Samuel é o amante, e Canavarro lhe tem idolatria). Num dos encontros de Cláudia com Canavarro, o narrador discute o papel dos dois na história, questionando o posicionamento que transforma a mulher em vítima incapaz de assumir e reivindicar seus direitos e obrigações sociais:

Como tal, que direito tinha o lobo de lhe dizer: "Eu tinha a certeza de que virias," como se pretendesse significar não ignorar o princípio moral que norteava a história? E tal situação era tão mais desagradável quanto era certo que a floresta não podia abstrair-se do lobo feroz, pois não era conveniente desligar o prazer duma aventura do imanente conhecimento da sua provisoriedade. A floresta tinha que acabar-se no lobo feroz antes que a menina do capucinho encarnado sucumbisse, maravilhada e estúpida, no meio dos ramos enleantes e cerrados da floresta. (264) 
Se em O ângulo raso já havia referências à mitologia dos contos de fada, em Terra sem música a reescritura das histórias e lendas ganha uma conotação ainda mais sardônica e explícita. Nesse texto, Botelho usa a paródia de uma forma mais desmistificadora, questionando e reposicionando a imagem feminina que a mitologia dos contos de fada criara. No capítulo "O Livro de Pitch," Antônia reconta a "verdadeira" história do Barba Azul caracterizando-o como neurastênico, desconfiado e horripilante. Segundo a versão de Antônia, havia-se encontrado um documento ("no arquivo secreto dum fabricante de rolos, na altura instalado em Mitilene") que serviu para esclarecer e reavaliar a história tradicional do Barba Azul. A linguagem irônica se interpõe sobre o texto clássico comentando e discutindo certas mitificações em torno do comportamento das mulheres.

Adaptado aos tempos atuais, a reescritura do conto descreve um Barba Azul que possui cadeias de hotéis, monopólios de aço e trusts na América do Sul, casado com uma bela e jovem senhora que exibe a mesma curiosidade das "pretéritas esposas" de visitar o quarto que o marido traz sempre trancado. A princípio, a história parece ser uma simples modernização irônica e cômica do conto clássico. No entanto, interrompendo a trágica ascensão de eventos (quando o Barba Azul ia matar a sua esposa), a narrativa de Antônia deixa o leitor saber apenas que os documentos encontrados mencionam que Barba Azul foi morto e "o veredito foi o de morte provocada em legítima defesa" (208). O narrador transfere ao "leitor a elaboração de qualquer síntese" e "se moralidade encontrar nesta biografia" pede o favor de expor corajosamente os fatos às futuras gerações (208). Nessa história e nas conclusões geridas, Botelho descreve a fase heróica do movimento/luta feminista exemplificando a busca de um espaço que, freqüentemente, se fez num sistema de confronto e acusações.

Em Xerazade e os outros, o próprio título do romance estabelece uma associação com as Mil e uma noites. No texto clássico, para se manter viva, Scherezade usa o estratagema da 
linguagem e da fala para persuadir o rei a poupar-lhe a vida. Botelho apresenta uma Maria Luísa (apelidada de Xerazade) que, ao contrário da personagem das Mil e uma noites, não usa o poder da palavra para mudar o seu destino. Ela se cala e se submete à degradação psicológica do marido para ter direitos de usufruir as vantagens financeiras da vida sócio-econômica que ele lhe ofereceu. A sua recusa de voltar para o marido e a sua habilidade de verbalizar tal fato desconstroem, no final da narrativa, a mitologia previamente estabelecida.

O debate masculino sobre a "liberdade" feminina aparece mais explicitamente em Lourenço é nome de jogral em que Firmino acredita que "a mentalidade geral está a evoluir" (141). A ótica otimista de Firmino se apoia no fato de considerar que exigir-se oportunidades sexuais e profissionais igualitárias é um grande avanço social para as mulheres. Lourenço, no entanto, considera que tal "avanço" é uma questão superficial pois "tudo está a processarse de fora para dentro" (141-42). Firmino contra-ataca, dizendo-lhe que "destruir um tabu já é um começo" e que "as reivindicações femininas processam-se aliás, noutros campos, nomeadamente no profissional" (142). Lourenço propõe que a liberação feminina em Portugal não passa de um elemento superficial bastando-se analisar a propagação da pornografia que se apresenta camuflada pela aparência de erotismo ou liberdade sexual. Concluindo o seu argumento, Lourenço condena a conivência feminina, a alienada participação das mulheres que não percebem como a pornografia (mascarada de erotismo) contribui para a subordinação feminina e propaga a degradação sexual da mulher: "[a] 'liberdade' da mulher, aí a tens parodiada em todas as revistas pornográficas, em cartazes e painéis publicitários, muito funcionalmente sexy, comprometida a serviço de todas as sociedades de consumo... Enquanto o 'produto' não se descobrir logrado, a rentabilidade está assegurada” (142). A crítica de Lourenço à participação da mulher na pornografia é, de certa forma, uma crítica à corrente feminista considerada "pró-sexo" que se apoia na questão da liberdade sexual. As análises de Firmino 
e Lourenço refletem os debates dentro do próprio movimento feminista em todo o mundo.

Botelho retrata as sutilezas da visão patriarcal que, não se interpondo por leis e decretos, tenta, sem muito sucesso, dominar através do controle de duas áreas específicas: a criatividade e a sensualidade femininas. Em O ângulo raso, Tom sonha pintar Lúcia dormindo (imagem da suma passividade), representando-a estereotipada e simulada em flores e feras. Em Festa em casa de Flores, numa linguagem mais direta, Botelho descreve as tentativas de Carloto - "pintor dominical e ortodoxo" (13) - de retratar o gozo orgásmico e a sensualidade da sua amante. Esforçando-se para captar o gozo quintessencial feminino na pintura, todos os domingos, Carloto se isola no seu "lúdico labor" para "vitalizar uma mulher nua deitada (como a Olympia de Manet), porém arfante, de boca entreaberta e cabeça descaída" (Festa 13).

No entanto, Carloto não consegue fazer a sua Olympia resplandecer de gozo e paixão. A sua Olympia parece desafiá-lo transformando a sua tentativa de lhe retratar o orgasmo numa caricatura, num quebra-cabeça mal ajustado. O retrato parece indicar que Carloto - na sua ânsia de captar e retratar o que considera a essência da sexualidade feminina - pode pintar a sua Olympia nua, pincelar-lhe os órgãos sexuais, desenhar-lhe a boca e os lábios, contornar-lhe o corpo. Não conseguirá, no entanto, preencher-lhe o olhar e dominar-lhe a expressão que espelharia os pensamentos, emoções e desejos. Por isso, o retrato parece sempre inacabado. Nesse texto, Botelho analisa a tentativa patriarcal de dominar a sensualidade feminina. Esta é uma das áreas que tem atraído mais a atenção da crítica feminista recente pois é onde a mulher pode exercer maior domínio sobre si mesma.

Em Dramaticamente vestida de negro Botelho retoma o tema da pintura. Desta vez, porém, a pintora é uma mulher octogenária que incorpora na sua pintura - e na sua vivência também - os excessos brughelianos por que as personagens femininas das suas obras anteriores tanto ansiaram. Botelho apresenta uma mulher que 
pinta (Cleo), outra que escreve a que pinta (a jovem jornalista Clara) e outra (Laura) que lê, às escondidas, a biografia da pintora escrita por sua filha. Os eventos vão se desenvolvendo de maneira cinematográfica e num ritmo quase folhetinesco.

Dramaticamente vestida de negro descortina a alma de Laura que, vicariamente, vive a truculência de emoções brughelianas através da leitura que faz da vida de Cleo. As pinceladas dos eventos diários e da pintura de Cleo intercalam-se à história rotineira de Laura, à efervescência juvenil de Clara e à "fabulosa" biografia de Cleo que Clara está escrevendo. Tal leitura biográfica - entremeada às leituras dos textos de Fernando Pessoa - torna-se o trampolim que leva Laura a ler a si mesma na busca de um significante que possa elucidar o significado de envelhecer numa sociedade codificada para premiar juventude e beleza. Elaborando sobre a efemeridade das relações humanas, a volatilidade dos afetos e o desamparo da solidão, Botelho prima pela análise interior das personagens, sem perder de vista a relação dessas pessoas com o seu meio sóciocultural.

A relação - discutida em obras anteriores a Dramaticamente vestida de negro - entre ler, escrever e pintar como forma de representar e re-avaliar a posição das personagens femininas, atinge uma característica auto-referencial de culminância nesse romance. Usando técnicas cinematográficas de corte e colagem, Botelho passeia pelos labirintos da geometria dos personagens, expondo a obliquidade das relações humanas. Ao fazê-lo, descortina o peso de envelhecer para as mulheres numa sociedade em que juventude e beleza estabelecem a tônica da auto-estima. Entremeando várias histórias e muitos discursos, Botelho apresenta três níveis de relações que se trançam, desvendando um discurso plissado de complexas relações pessoais e de referências literárias. Os dias sempre iguais de Laura são divididos entre aulas, música, leituras, conversas com a filha e a empregada, a aceitação passiva da sua condição de mulher divorciada (trocada por uma mocinha da idade da sua filha) e o seu relacionamento ocasional com o amante casado. Súbitas mudanças 
ocorrem afetando a vida de Laura (Cleo morre, a narrativa de Clara pára, o seu gato de estimação morre, a filha e a empregada resolvem se mudar, o amante decide não vê-la mais). Nesse ponto da narrativa, todas as relações pessoais/afetivas dela, aparentemente cômodas e estabelecidas, parecem chegar ao fim, desestruturando completamente a sua rotina e a sua falsa estabilidade emocional.

Dramaticamente vestida de negro é, por excelência, o livro de crise de Botelho. Enquanto nos outros romances o rito de passagem (ao reconhecimento das suas potencialidades pessoais) ocorre com protagonistas mais jovens, nesse último romance, o rito de passagem se apresenta através da conscientização de estar na meia idade, rumo à terceira idade. Situada num sistema de ideologias culturais em que ela se mede e se vê através do reflexo das suas relações com os outros (principalmente a nível afetivo), Laura se sente "dramaticamente vestida de negro" quando o peso de envelhecer lhe aponta a solidão como o futuro que a espera. A ternura e o profundo desassossego com o significado cultural do envelhecer que inundam o final do livro, a transparência e o aprofundamento da análise das relações pessoais - violentamente e dramaticamente marcadas fazem desse último romance de Fernanda Botelho uma análise também auto-referencial. O choro de Laura ao se abraçar a Filomena torna-se representativo do seu momento epifânico que começara com a morte de Cleo. A tomada de consciência de Laura de si mesma e a sua saída de um torpor vital em que se imiscuíra abrem um leque de significações em que o final do romance se anuncia como o começo de uma outra história muito mais humana e sentida.

Se nos romances de Botelho, as personagens femininas são inicialmente representadas em círculos concêntricos da dominação pátria, elas aprendem a negociar relações de poder, reorientando imagens, redimensionando paradigmas e recriando potencialidades para si mesmas. Os textos de Botelho estabelecem uma epistemologia que desestrutura as antinomias entre o público e o privado, o emocional e o intelectual, o subjetivo e o objetivo. As personagens femininas se recusam a aceitar os limites de uma perspectiva/ 
proposta de vida impostos pelo universo da razão logocêntrica e circunscritos pelo imaginário do mito. Como Laura, elas podem, "dramaticamente vestidas de negro", ultrajar as expectativas de um comportamento sujeito a padrões e normas sócio-culturais.

Como analisado, as personagens femininas dos romances de Botelho se anunciam cheias de dúvidas e temor, para chegar no final dos romances corajosas, firmes, denunciando as tramas da corrente androcêntrica. Elas "acordam," se olham, se interrogam e perfazem a trajetória do "ângulo raso," rota definida por Antônia (Terra sem música) num poema sem título, composto do fim para o princípio:

$$
\begin{aligned}
& \text { É o momento ou nunca. Toda a vida } \\
& \text { do sagitário fui, desvanecida, } \\
& \text { mártir, presa, objecto - só destino. } \\
& \text { Ergo-me do pó. De pronto afino } \\
& \text { as cordas retorcidas de uma harpa, } \\
& \text { as escamas lodosas de uma carpa, } \\
& \text { a fúria assassina de um Maloch, } \\
& \text { o despeito, feito amor, } \\
& \text { de um Cristo ad hoc. (247) }
\end{aligned}
$$

Essas mulheres sonham com um exagero de viver brugheliano, sem medos, sem punições, sem censura. É, através da volúpia de desejar definir-se, que elas se questionam, se desencontram, amam, desamam, mas sobremaneira tentam escapar dos "destinos" para elas traçados pela visão patriarcal. Elas se transformam em pessoas que questionam o sistema em que vivem e, finalmente, munem-se de coragem para mudar os padrões do seu relacionamento social e pessoal. No momento crítico das suas decisões, libertam-se da moldura sócio-cultural em que se encontravam aprisionadas e adotam uma atitude desalienante de auto-crítica, determinação e de poder sobre as suas próprias vidas. 


\section{Referências Bibliográficas}

AZEVEDO FILHO, Leodegário. Fernanda Botelho: o labirinto em forma de romance. Colóquio/Letras 49 (Maio 1979) 34-40.

BOTELHO, Fernanda. As coordenadas líricas. Lisboa: Edições Távola Redonda, 1951.

. O ângulo raso. (1957) Lisboa: Contexto, 1986.

. Calendário privado. (1958) Lisboa: Contexto, 1986.

. Dramaticamente vestida de negro. Lisboa: Editora Presença, 1994.

. O enigma das sete alíneas. (1956) Lisboa: Editorial Organizações, 1963. 1989.

Esta noite sonhei com Brueghel. (1987) Lisboa: Contexto,

. Festa em casa de flores. (1989) Lisboa: Contexto, 1990. - A gata e a fábula. (1960) Lisboa: Contexto, 1987.

. Lourenço é nome de jogral. (1971) Lisboa: Contexto, 1991.

. Referência indispensável. Em "Camilo visto por escritores de hoje". Jornal de Letras 5 Junho 1990: 6.

. Significado actual da obra de Aquilino Ribeiro. Colóquio/ Letras 85 (1985): 94-95.

. Terra sem música. (1969) Lisboa: Contexto, 1991.

. Xerazade e os outros: romance/tragédia em forma de. (1964) Lisboa: Contexto, 1989.

CARMO, José Palla e Carmo. Literatura e "literariedade": Xerazade e os outros, de Fernanda Botelho. Do livro à leitura: ensaios de crítica literária. Lisboa: Publicações Europa-América, 1971.

GUEDES, Teresa Moura. Bruegel e Fernanda Botelho. Colóquio/ Letras 102 (Março-Abril 1988): 102-06.

LUPECKI, Maria Lúcia. À margem de Terra sem música. Suplemento Literário de Minas Gerais. 26 de Julho de 1969: 8. 
LUPECKI, Maria Lúcia. À margem de Terra sem música. Suplemento Literário de Minas Gerais. 02 de Agosto de 1969: n. p.

MENDONÇA, Fernando. As relações humanas e o mito da profundidade. O romance português contemporâneo (19301964). Assis: Faculdade de Filosofia, Ciências e Letras, 1966.

. Fernanda Botelho: Xerazade e os outros: romance (tragédia em forma de): "ficção de autoria feminina ou o sabor da solidão." A Literatura portuguesa no século XX. São Paulo, HUCITEC; Assis, Faculdade de Filosofia, Ciências e Letras, 1973.

MOISÉS, Massaud. Fernanda Botelho. Pequeno dicionário de literatura portuguesa: crítico, biográfico, bibliográfico. São Paulo: Cultrix, n. d.

OLIVEIRA, A. Lopes de. Fernanda Botelho. Escritoras brasileiras, galegas e portuguesas. Braga: Tipografia Silva Pereira, n. d.

PALA-FERREIRA, João. Pretérito imperfeito. Lisboa: Estúdios Cor, 1974.

POPPE, Manuel. Humanidade, sinceridade, autenticidade. Literatura e absurdo: Xerazade e os Outros. Testemunho pungente: Terra sem música. Viver, sim, mas como?: Lourenço é nome de jogral. Temas de literatura viva/35 escritores contemporâneos. Lisboa: Imprensa Nacional-Casa da Moeda, 1982.

RABELO, Maria da Glória Martins. Fernanda Botelho: a literatura como matéria Romanesca. Minas Gerais Suplemento Literário 597 (11 Março 1978): 6-7.

. Fernanda Botelho: a literatura como matéria romanesca (II). Minas Gerais Suplemento Literário 599 (25 março 1978).

REBELO, Dulce. A gata e a fábula - 1960 - Fernanda Botelho. A propósito do Prémio Camilo Castelo Branco. Vértice: Revista de Cultura e Arte 228 (Setembro 1962): 423-28.

RIBEIRO, Maria Aparecida. A origem da estrutura trágica de Xerazade e os outros. Colóquio/Letras 36 (1977): 39-44. 
SACRAMENTO, Mário. Fernanda Botelho. A gata e a fábula (romance). Ensaios de domingo II: interpretação literária. Porto: Editorial Inova, 1974.

SADLIER, Darlene. Modernism and Feminism in Fernanda Botelho's Xerazade e os outros. The Question of How: Women Writers and New Portuguese Literature. Westport, Connecticut: Greenwood Press, 1989.

TRIGUEIROS, Luís Forjaz. Novas Perspectivas: Temas de Literatura (1962-1968). Lisboa: União Gráfica, 1969.

\section{Resumo}

Fernanda Botelho situa as personagens femininas dos seus nove romances (escritos entre 1956 e 1994) no contexto histórico-social e na tradição literária portuguesa, analisando os papéis femininos e a representação da mulher na pintura e na literatura. As mulheres nos seus romances criticam as mitologias repressoras, a domesticação do desejo e a celebração do "eterno feminino", parodiam a misoginia patriarcal e examinam as tensões sociais, políticas, culturais e religiosas em Portugal. Seus textos analisam a trajetória de conscientização, auto-análise e auto-crítica das personagens que, no processo, também avaliam e rejeitam os parâmetros sócioculturais a elas impostos.

\section{Abstract}

Fernanda Botelho places the female characters of her nine novels (written between 1956 and 1994) in Portugal's social, historical and literary context. Her female characters criticize repressive mythologies, the domestication of desire, and the celebration of the "eternal feminine". They parody patriarchal misogynism and also examine the social, political, cultural, and religious tensions in Portugal. Botelho describes her female characters' process of consciousness-raising, self-analysis, and self-criticism while evaluating the social and cultural parameters imposed on women in Portugal. 